\title{
Survey of Customer's Service Expectation and Quality Perception to G.S.M Services in Ondo State
}

\author{
Gabriel Kolade Olorunleke, Ph.D \\ Department of Business Administration \\ Adekunle Ajasin University, Akungba Akoko Ondo State, Nigeria \\ E-mail: Gabriel.olorunleke@aaua.edu.ng; Kolaleke62@gmail.com
}

Received: September 10, 2020 Accepted: November 5, 2020 Published: November 23, 2020

doi:10.5296/ber.v10i4.17988

URL: https://doi.org/10.5296/ber.v10i4.17988

\begin{abstract}
s
The satisfaction derived from services rendered by a company goes a long way in determining the response of consumers to these offerings and this can be either a positive or negative response. Hence, this study looks at customer's purchase expectations and actions to GSM offerings in Ondo State. To achieve the objective above, this study employs a survey research design. A sample of 385 respondents was selected using multistage sampling, out of a population of about 906,557 . The result confirmed that $85 \%$ of the GSM subscribers cannot guarantee adequate satisfaction with the quality of services with only one network, hence they use more than one network at the same time, switching over to the next each time they have the problem with one network. Secondly, the study finds that network accessibility has the highest customer's expectations or satisfaction being met; followed by ease of obtaining call cards. Though tariff cost, network quality and bonus do not count much on expectation or satisfaction in Ondo State. Thirdly, both network accessibility and bonus have negative impacts on consumer perception of network quality but tariff cost, ease of obtaining cards, choice of the network have a positive impact on the perception of network quality. In conclusion, GSM companies need to be conscious of inconveniences encountered by their subscribers and they should do more to take care of those subscribers particularly in areas identified in this study. The study recommends that the companies should put preference on network accessibility to meet the customer expectations and that one of the ways to improve on GSM network quality is to educate consumers on their rights and privileges so that they can fight for their right. This should be championed by the supervising organ of government on GSM communication which is Nigeria Communication Commission (NCC).
\end{abstract}

Keywords: Consumer response, Service Offering, GSM subscribers, Network Quality 


\section{Introduction}

The world is quick turning into a worldwide village as a results of innovation and technological developments being practised daily. In order to realize this development, communication has compete a significant role. At the centre of this, is world communication network that is indispensable. A remarkable action is that the remote lines phone system that comes in either fastened remote lines or the world System of Mobile Communications (GSM) (Wojuade 2005). The telecommunication sector in Nigeria achieved a major boost with the emergence of service providers such as ECONET (now Airtel) in 2001, MTN also in 2001, GLOBACOM in 2003 and Etisalat in 2008.

Telecommunication industry, as far as increase in network centers, had encountered numerous adjustments arrangement of wide scope of network facilities, for example, prepaid call plans, month to month subscription plans, universal roving, multimedia electronic messaging service (MMS), Wireless Application Protocol (WAP), broadband web plans, 3G subscribers to paid and post-free endorser and even $4 \mathrm{G}$ or $5 \mathrm{G}$ network. It's now not a gainsaying, therefore, that network suppliers in Federal Republic of Nigeria like MTN, GLO Mobile, ETISALAT and AIRTEL have step by step and consistently moved their focus from the supply of network coverage to provision of quality services. The telecommunication trade has created to be exceptionally competitive as numerous organizations battle for the thought of subscribers. That makes it easier for subscribers to form selections that area unit profitable and satisfactory. With the launch of their services, Nigerians were delighted and full of expectations of a break from the bitter past, to improved services, improved business transactions and general expectations of improved socio-economic wellbeing. However, the extent to which these expectations have been met calls for concern. In order to penetrate the market, the new entrants such as Etisalat now called 9mobile and Airtel employed various strategies such as the introduction of series of free reduction on all calls - both national and international, packet change for access to the net and MMS for causing and receiving photos and video (NCC, 2012).

Mobile Telecommunication Network (MTN) and Global Communications Network (GLO) have employed same strategies of a downward reduction in tariffs of their major prepaid products and a wide range of improved and quality services (NCC, 2011). These strategies became imperative in order to retain customers in the face of stiff competition in the industry. To curb the incidence or scenario of switching from one network to another and increase competition in the telecom industry, Mobile Number Portability (MNP) regulation was introduced in Nigeria mobile market on 22nd April 2013 (NCC, 2013). The MNP allows subscribers to use only one line while operating on the platform of their choice. It allows subscribers to migrate from one network to another without changing their old numbers (NCC, 2013). Packet shift for access to the web and MMS for causing and receiving photos and video (NCC, 2012).

Mobile Telecommunication Network (MTN) and but the most important is the timing and frequency when MNP could be performed. Consequently, subscribers still prefer to switch a telecom service provider (NCC, 2013). The issue is not only meeting expectations but the organization must be interested in areas where consumers expect quality. The satisfaction 
derived from service rendered by a company goes a long way in determining the response of the consumer to their products. The satisfaction of customers, gaining more customers and retaining its customer base is the ultimate aim of every business organization. As such an understanding of the service offered by network providers will assist in understanding and measuring the various responses of consumers. Previous researchers study in the telecommunication industry, Booz, Allen \& Hamilton, (1995); Danaher \& Rust, (1996); Bolton, (1998), proposed four factors, network quality, price, client care and private edges as key drivers of the client price of cellular services. However, the research carried out does not take into cognizance these specific responses of a customer to the various services provided i.e. what they actually do, that cumulate to either loyalty or switching in their response behavior. In the Nigeria context, consumer satisfaction condition with quality service conveyed by telecom industry in Nigeria is likewise not clear as there's lean documentation on the problem.

Frempong and Henten, (2004) stressed that the objectives set by the government have simply halfway been met, particularly regarding the rural areas communication advancement where nature of quality is still low and has even disintegrated on certain indicators. Henceforth, customer's satisfactions with some quality description in their own word need to constantly screen. It was observed that consumers of telecommunication product and services in Nigeria are quite varied, in their attitudes, tastes, needs and expectations (Ndukwe, 2008). Arguably, these differences explain in part why consumers don't subscribe to the same networks. Issues, for example, insufficient service coverage, arrange, network inaccessibility, high call drop rates and postponements in a ring set time, connection error and voice transformation among different protests by subscribers are rampant. Because of the low quality service, numerous subscribers have twofold chips considering the challenges of swapping starting with one network then onto the next especially in occurrences where the subscribers have just one phone. In spite of these objections, a survey of expectations of the offerings by customers on the street has not been carried out. This study will objectively and like to examine the behaviour of consumers in the use of GSM services; find out if demographic variables have anything to do with satisfaction in Nigeria; examine the consumer expectations and GSM service offerings and examine the specific perception of a consumer to service quality. The study will contribute and assist the telecommunication operators companies to be conscious of inconveniences encountered by their subscribers. It will also assist and educate consumers on their rights and privileges so that they can fight for their right. The remainder of this chapter has been organized as follows. Section on conceptual issue provides theoretical and conceptual issue of the study.

In section methodology, the results are analysed. In section results, a discussion of the results is given. Section conclusion concludes the chapter.

\section{Conceptual Issue}

\subsection{Telecommunication in Nigeria}

It has been argued that Nigeria telecommunication industry is the most spirited and competitive sector once the fossil oil trade. Nigerian telecommunication trade has seasoned extraordinary growth inside the short amount it started (1999-date). African country is that 
the largest and quickest growing mobile market in continent and one amongst the quickest within the world (Ndukwe, 2004). MTN, that is that the first telecommunication company in African country, was given license to work followed by ECONET that is currently referred to as Airtel and Globacom joined, followed by Etisalat. With the exception of these four major networks, there are unit of others that are regionally based mostly. Telecommunication is each dynamic and capital intensive and incorporates an immense effect on the event of alternative sectors within the economy like health, business and education. Telephone services that were formally restricted to urban areas in African country is currently nearly all told the agricultural areas of the corporate. Telecommunication services like the net have vastly contributed to the rise of business activities and thence the expansion within the economy. Traders can currently order merchandise from any region of the country while not essentially traveling for such transactions. Telecommunication play a very important role for the socio-economic development of a rustic. (Sobhan, 2002).

\subsection{Mobile Phones}

Mobile Phones, otherwise referred to as telephone, cellular phone or hand phone, could be a device which will create and receives phone calls over a large geographic region (Heeks, 2008). A smartphone combines the services of the internet and a mobile phone (Cha, Seo, 2018). Modernization of technology has made peoples life easier and had contributed significantly to the social economic wellbeing so far (Anjali, 2018). However, Researches have shown that customers are not always satisfied with most of these service offered to customers which make them resort to switching their service provider in order to resolve the issue or in a bit to getting a better value from a less expensive service (Heeks, 2008).

\subsection{Theoretical Conception}

The theory of Planned Behaviour states that a person's intention predicts behaviour. The theory emphasized that the components of personal factor (social influence and issues of control) have an effect on a person's intentions (Ajzen \& Fishbein, 1980). People have certain outcome beliefs of their action. Beliefs form positive or negative attitudes toward the intended behaviour. Other people also have beliefs toward one's action which is demonstrated by social influence, normative expectation or social pressure and is referred to as the subjective norm. Issues of control are related to an individual's beliefs of how he or she is able to perform the desired action. This is referred to as perceived behavioural control.

According to the Theory of Planned Behaviour, people tend to perform an action when they have positive evaluations about the desired behaviour, they feel social pressure to do it and they also feel capable of doing so (Ajsen, 2005). In general, the stronger the intention to behave in a certain way, the more likely it will be performed given that no constraints to behaviour exist. Further, if there is no issue of control, behaviour can generally be anticipated from an individual's intentions (Ajzen, 1991). For example, if one's intention is to use a credit card as a payment method. Beckett (2000) identifies two broad attitudinal factors that influence consumer behaviour. These are uncertainty and involvement. The more specific the outcome of a purchase decision anticipated, the lower the degree of uncertainty and vice-versa. Consumers' ability to predict outcomes are based on their cognitive abilities and 
to the degree of uncertainty is lower. Also, if the information is widely available and accessible, it results in lower uncertainty (Beckett 2000).

The existence of uncertainty makes purchase decision-making more difficult for consumers. Thus, a key element in consumer buying behaviour process is the reduction of uncertainty (Beckett 2000; Williamson 1985). The perceptions of risk are also lower if uncertainty is at justifiable level (Howcroft, Hewer \& Hamilton 2003). According to Beckett (2000), the other key determinant of buyer behaviour is the consumer's interest toward a product or a service. The extent to which consumers understand whether the service meets their goals and values will increase the consumers' interest toward the service.

Martin Fishbein \& Icek Ajzen (1980) theory of reasoned Action was developed by as an improvement over information integration theory. Reasoned actions add another element in the process of persuasion, behaviour intention. Reasoned action is explicitly concerned with behaviour. However, this theory also recognizes that there are situations (or factors) that limit the influence of attitude on behaviour. For example, if our attitude leads us to want to go out on a date but we have no money, a lack of money will prevent our altitude from causing us to go on a date. Therefore, reasoned action predicts behavioural intention, a compromise between stopping at attitude predictions and actually predicting behaviour. Reasoned action (because it separates behaviour intention from behaviour) also discusses the factors that limit the influence of attitude (or behavioural intention) on behaviour.

The theory suggests that purchase intention is the surrogate measure of actual purchase (Summers \& Belleau 2006). The best predictor of behaviour is the intention to perform (Fishbein \& Ajzen 1980). The theory of Reasoned action uses two elements -attitudes and norms (or the expectation of our people) to predict behavioural intent. That is, whenever our altitude leads us to do one thing but the relevant norms suggest we should do something else, both factors influencing our behavioural intent.

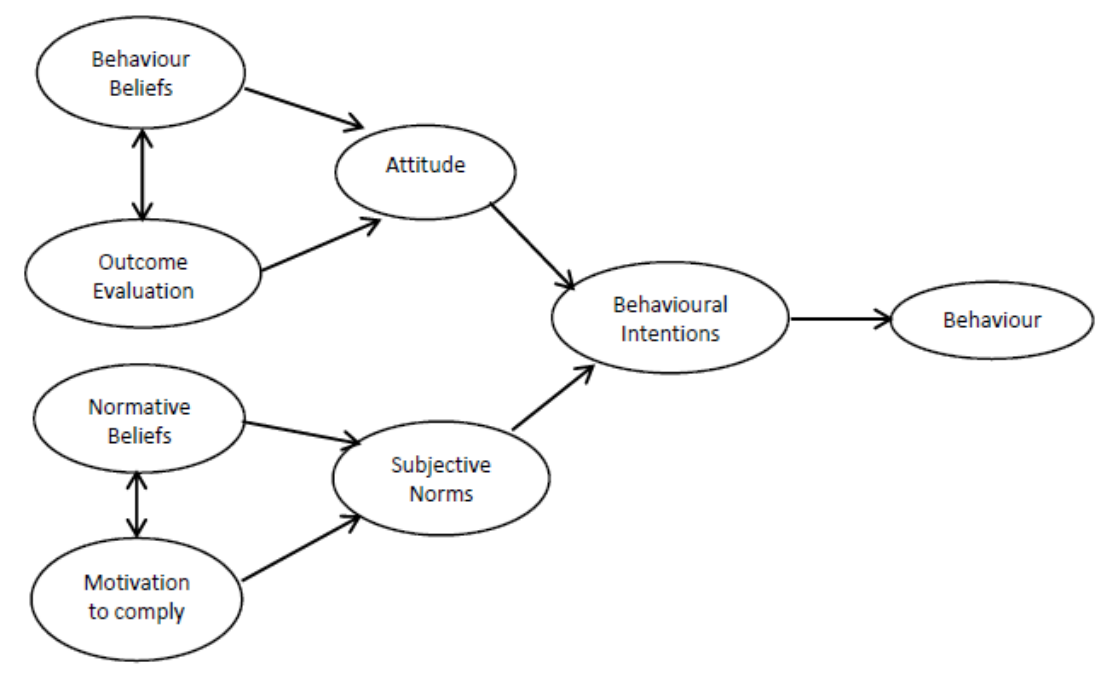

Figure 1. Predicting Behaviour Intent

Source: Fishbein and Ajzen(1980) 
Product and complete temperament gift real opportunities for marketers to require advantage of consumer's connections to numerous brands they provide (Milles, 2004). Brands typically have personalities - some embrace anthropomorphic traits and even gender. These complete personalities facilitate form client responses, preferences and loyalties (miles, 2004). Every individual incorporates a perceived self-image as bound a particular reasonably person with certain traits, habits, possessions, relationships and ways that of behaving (Barbara, 1998). Customers oft commit to preserve, enhance, alter or extend their self-images by buying product or services and searching at stores they understand as per their relevant self-image(s) and by avoiding product and stores they understand aren't (Barbara, 1998). The speculation of temperament is thus relevant to the current study as a result of it'll change network supplier to understand that totally different roles need different ability set and aptitudes that area unit tied to temperament. Not each temperament is a stimulating leader. Therefore, network suppliers got to acknowledge the importance of temperament once searching for candidates to fill job openings.

Behaviour and cognitive theories both contribute to an understanding of consumer behaviour. Behavioural theorist view learning as observable responses to stimuli, whereas cognitive theorist believes that leaning is a function of mental processing. Mackintosh (1983) identified three major behavioural learning theories as classical conditioning, instrumental conditioning and observational (vicarious) learning. The principles of classical conditioning that provide theoretical underpinnings for many marketing applications include repetition, stimulus generalization, and stimulus discrimination (Mackintosh, 1983).

Neo-Pavlovian theories view traditional classical conditioning as cognitive associative learning rather than as reflexive action (Mackintoch, 1983). Instrumental learning theorists believe that learning occurs through a trial- and -error process in which positive outcome (i.e rewards) result in repeat behaviour. Positive and negative reinforcement can be used to encourage the desired behaviour (Margret, Campbell \& Kevine, 2003).

The temporal arrangement of repetition influences however long the training material is preserved (Margret et al, 2003). Repetition produces more initial learning than distributed repetition. However, learning sometimes persists longer with distributed (i.e opened up) reinforcement schedule (Margret et al., 2003). Cognitive learning theory holds that the sort of learning that characterizes most humans is problem-solving. The psychological feature theorist could be a concern with however data is processed by the human mind: however it's hold on, preserved and retrieved (Michael, \& Claes, 1987). A straightforward model of the structure and operation of memory recommend the existence of three separate storage units: the sensory store, short-run store or memory and long store. The processes of memory embrace rehearsal, encoding, storage, and retrieval (Margret et al., 2003).

Involvement theory proposes that individuals have interaction in restricted information science in things of low importance or connection of term and in in depth information science in things of high connection (Rajeev \&Shirley, 2003). Peng \& Wang (2006) opined that the decision of selling to win and keep customers by making relative worth chain in an exceedingly manner that culminates additional contacts and dipper accords, frequency selling 
and economical operations. Murray (2014) emphasised that firms generally build complete loyalty through robust advertising and selling campaigns that influence customers additionally high-quality product or services. The importance of this theory to this study is that complete loyalty of network supplier results in enhanced market share, higher profits and higher goodwill among customers. Market share represents the quantity of the market's total sales that one network provides earns once subscribers build purchases. Complete loyalty permits a supplier to plug and advertise its services within the market. Therefore, building loyalty by giving quality services or undercutting another company's complete loyalty through change and improve market share.

The present study is anchored on the theory of planned Behaviour that people tend to perform an action when they have positive evaluation about the desired behaviour, they feel social pressure to do it and they also feel capable of doing so.

\subsection{Customer Satisfaction and Quality Perception}

The response of consumers to services offered could be an important objective for businesses. The satisfaction of customers is a vital tools to be consider in obtaining a positive response from them. Firms need to know the factors that influence the formation of an individual service expectation in an online environment and to established the influence of those expectation on client likelihood of recommending the service before they are even used (Mendez- Apavicio, Izquierdo-yusta \& jimenz, 2017) customers also can answer services offered by being loyal to the corporate or change to the competition. Some recent statistics demonstrate the advantages of fine client satisfaction and value of poor satisfaction has on businesses, smart client satisfaction has an impression on the profitableness and success of each business.

Parker and Mathew (2001) identified two basic definitional approaches to customer satisfaction. The first approach defines customer satisfaction as an outcome while the second approach views it as a process. It is, however, important to note that these two approaches are not exclusive rather complimentary. As a method, expectation significantly affect perceived enjoyment, perceived ease of used and satisfaction. Satisfaction has positive direct effect or repurchased intention (Ashtag, Yun, Waheed, Muhammed \& Farruka, 2019). As a process, customer satisfaction is defined as an evaluation between what was received and what was expected (Johnson, 2001; Gustafson, Johnson \& Roos, 2005), emphasizing the perceptual, evaluative and psychological processes that contribute to customer satisfaction (Vavra, 1997). The outcome approach of customer satisfaction is defined as the end- state of satisfaction resulting from the experience of consumption. This is a post-consumption state that can be an outcome that occurs without comparing expectations (Oliver, 996). Customer satisfaction can be defined as an experience-based assessment made by the customer of how far his own expectations about the individual characteristics or the overall functionality of the services obtained from the provider have been fulfilled. (Gerpott, Rams \& Schindler, 2001).

Customer satisfaction has been perceived as a key determinant behind the customer's call to go away or stick with a company (Thakur, 2011). By definition, client satisfaction is that the "customer's fulfilment response" Rust and King Oliver, 1994). it's a private feeling of either 
pleasure or disappointment ensuing from the analysis also as AN emotion-based response to a service (Dhandabani, 2010 \& Loke et al., 2011). Hossain \& Suchy (2013) explored the influence of client satisfaction on client loyalty in telecommunication industry by focusing on communication, value structure, added service, convenience, sales-promotions and client service. The study found that all the factors have positive correlations with client loyalty except sales-promotion.

Switching behaviour could be a client behaviour wherever the behaviour of the customers differs supported the satisfactory level of the customers with the suppliers or corporations. Shift behaviour may be enunciated because the method of being loyal to 1 service and shift to a different service, thanks to discontentment or the other issues. Even though a client is loyal to a specific complete once the complete doesn't satisfy his wants the buyer switch to a contestant complete. The price that is incurred throughout the switching method is named shift price. client loyalty is outlined because the degree to that a client exhibits repeat buying behaviour from a service supplier, possesses a positive attitudinal disposition toward the supplier, and considers victimization solely this supplier once the necessity arises. (Gremler and Brown, 1996).In the telecommunication industry, previous researches have prompt four factors that area unit key drivers of the client worth of cellular services. These embody network quality, price, client care and private edges. (Booz, Allen \& Hamilton, 1995, Danaher \& Rust, 1996; Bolton, 1998).

\subsubsection{Customer Value, Satisfaction and Retention}

Client worth plays an important role in promoting. Many firms have with success adopted the promoting conception since its emergence within the Nineteen Fifties. The result has been a lot of product, in additional sizes, models, versions and packages, offered to a lot of exactly target and sometimes smaller target markets (Murray, 2013). Today, marketers have accomplished that so as to crush competitors, they need to reach the complete profit potential from each and every client. Murray (2013) known the three drivers of a successful relationship between markets and clients as customer price, high levels of client satisfaction and building a structure that ensures client retention.

\subsubsection{Customer Value}

Murray (2013), outlined client price because the quantitative relation of the customers' perceived edges (economic, purposeful and psychological) to the resources (monetary, time, effort, psychological) accustomed get those edges. According to Bayer (2010), client price is that the distinction between the positive profit element of a service or product, as a live of the satisfaction of desires of a client and his disutility parts within the sort of the price of acquisition and utilization of the service (price, time etc.). Customers have the choice to decide on the choice with the simplest price once creating a procurement call, as an example, the one with the simplest cost- profit distinction (Menon, lid and Beutin, 2005). The flexibility to live the client's key demand is thus essential for the successful development of the primary sub-process of a customer relationship controlling-value creation (Gordon, 2013). Perceived price is relative and subjective. 
Product /service evaluation gap affect customer satisfaction and client behaviour. If the value which a client get by using the product/ service is lower than the product service evaluation, the customer get dissatisfied and will never use the product again (Yamanda, 2019). Customers understand what to expect, and that they feel that they're obtaining price for the resources they expend. Developing a worth proposition is that the core of successful positioning. This price proposition creates client expectations that the corporate should unendingly fulfil and even exceed as competitors attempt to convince their markets. Customers generally, feel satisfied and remain loyal to a particular firm as a result of the value they receive from it and its offering (Murray, 2013).

\subsubsection{Customer Satisfaction}

According to Valerie and Zeithamil (2006), customer satisfaction relates to the individual's perception of the performance of the merchandise or service in respect to his or her expectations. The construct of client satisfaction could depend on client expectation, past experiences and encounters with promoting stimuli. If a customer's expertise falls below expectations, he are disgruntled and customers whose expectations area unit exceeded are terribly happy or delighted.

Reichheld \& Sasser (1990) coupled the extent of customer satisfaction with client behaviour and known many classes of consumers. The first category, according to him I the completely glad customers (the 'loyalists') World Health Organization keep buying or 'apostles' whose experiences exceed their expectations and supply spoken regarding the corporate to others. The second category is the 'defectors' who feel natural or merely satisfied and are likely to stop doing business with the company. The third category, according to Reicheld \& Sasser (1990), is the consumer 'terrorists,' who have had negative experiences with the company and spared negative word-of- mouth. 'The fourth category are the Hostages' who are unhappy with the company but stay with the company because of the monopolistic nature of its product. The fifth category is the 'mercenaries' who are very happy customers however don't have any real loyalty to the corporate and will defect attributable to a cheaper price elsewhere. An organization ought to thence, attempt to make apostles, raise the satisfaction of defectors and switch them into loyalists, avoid terrorists or hostages and cut back the amount of mercenaries (Reichheld \& Sasser, 1990). The understanding of the customers' experience, their feelings about the offering and the extent to which they are satisfied is of paramount importance to the development of an organization's sustainable comparative advantage (Reicheld \& Sasser 1990).

\subsubsection{Customer Retention}

The principal goal of providing price to customers unendingly and a lot of effectively than the competition is to own and to retain extremely happy customers. This strategy makes it within the best interests of shoppers to remain with the corporate instead of switch to a different firm (Valerie \& Zeithamil, 1981). It is costlier to win new customers than to stay existing ones. Studies have shown that tiny reductions in client defections manufacture vital will increase in profit as a result of (i) loyal clients purchase a lot of merchandise (ii) loyal customer square measure less value sensitive and pay less attention to competitor's advertising (iii) serving 
existing customers, WHO square measure conversant in the firm's giving and processes is cheaper (iv) loyal customers unfold positive spoken and refer alternative customers (Velerie \& Zeithamil, 1981). Valerie \& Zeithamil (1981) stressed that selling efforts directed at attracting new customers square measure very costly and may be impossible to find new customers, especially in a saturated market. The use of the internet and digital marketer-consumer interactions have become the ideal tools used to tailor goods and services to the specific needs of consumers. This is usually referred to as 'one-to-one marketing'. It offers them additional values through increase client intimacy and retention to the company.

\section{Methodology}

A survey research design was employed for this study. The study population consist of Ondo residents who are subscribers of the major telecommunication operations and the number is 906,557 (NCC, 2013). The study sample of 350 was chosen from the population using Krejcie and Morgan (1970) statistics. Data were collected from participants resident in the three major towns with urban facilities including functional GSM and they are representative of the three senatorial regions of the state. The towns are Owo, Akure, and Okitipupa. The Cronbach Alpha was used to test the reliability of the questionnaire. The research instrument was a structured questionnaire, divided into two sections. The sections consist of the bio-data of the respondents and the post-purchase behaviour of subscribers to GSM in Ondo State. The questionnaires were both open-ended and close ended. The construct in the study was captured by a number of items in the questionnaire with each item being measured on five points Likert scale. In a bid to derive useful meaning from the data and examine the propositions of the study, the data from the survey was analyzed using SPSS. Descriptive statistics such as mean, percentages and frequency were and also ANOVA and regression were used.

\section{Model Specification}

The model specified for the analysis is as specified below.

1. $P S=f(M S, G)$

2. $P S=f(T C, N Q, B, N C, N A, E O C) 1$

3. $\mathrm{NQ}=\mathrm{f}(\mathrm{EOC}, \mathrm{TC}, \mathrm{NC}, \mathrm{NA}$, and $\mathrm{B})$

Where EOC $=$ Ease of obtaining card

$$
\begin{aligned}
& \text { TC }=\text { Traffic cost } \\
& \text { NC }=\text { choice of Network } \\
& \text { NA = Network accessibility } \\
& \text { B = Bonus provided for usage } \\
& \text { PS= Perceived Satisfaction } \\
& \text { NQ= Network Quality } \\
& \text { MS = Marital Status } \\
& \text { G=Gender }
\end{aligned}
$$




\section{1) Macrothink}

\section{Results}

Table 1. Do you have more than one network been used at the same time

\begin{tabular}{|l|l|l|}
\hline Do you have more than one network been used at the same time? & Yes & No \\
\hline
\end{tabular}

Source: Field Survey 2018

More percentage of our respondents carries more than one network per time, $85 \%$ of the respondents agreed that they have one than a network with them while $15 \%$ are with only one network. The reasons behind this are Inadequate service coverage, network congestion, network unavailability, high call drop rate, delay in the call set up time, error in connection and voice mutilation among others.

Table 2. Perceived Satisfaction

\begin{tabular}{|l|l|l|l|l|l|l|}
\hline NETWORK & N & Mean & $\begin{array}{l}\text { Standard } \\
\text { Deviation }\end{array}$ & $\begin{array}{l}\text { Std. } \\
\text { Error }\end{array}$ & \multicolumn{2}{|l|}{$\begin{array}{l}\text { 95\% Confidence } \\
\text { Interval for Mean }\end{array}$} \\
\cline { 5 - 7 } & & & & & Lower Bound & Upper Bound \\
\hline MTN & 236 & 34.8602 & 5.75765 & .37479 & 34.1218 & 35.5985 \\
\hline GLO & 92 & 35.9674 & 5.36872 & .55973 & 34.8556 & 37.0792 \\
\hline AIRTEL & 38 & 36.2105 & 5.51733 & .89503 & 34.3970 & 38.0240 \\
\hline ETISALAT & 15 & 32.6000 & 5.86515 & 1.51438 & 29.3520 & 35.8480 \\
\hline Total & 381 & 35.1732 & 5.67603 & .29079 & 34.6015 & 35.7450 \\
\hline
\end{tabular}

Source: Field Survey2018

Table 2 review perceived satisfaction with the telecom companies under reviews. It was revealed that those that are more satisfied are those that those use Etisalat with a mean of 32.600 and Standard Deviation of 5.866. But it was discovered that only 15 people out of 381 use Etisalat. Since the suitable base in how it may assist the network provider to satisfy the better. The next that is satisfied is MTN with a mean of 34.86 and Standard deviation of 5.758. They have the highest sampled subscribers' base which is 236 . Next is GLO with a M of 35.967 and SD of 5.369. The sampled subscribers' base is 92. Lastly, AIRTEL with a mean of 36.21 and Standard deviation of 5.865 . 
Table 3. Age Characteristic of Respondents

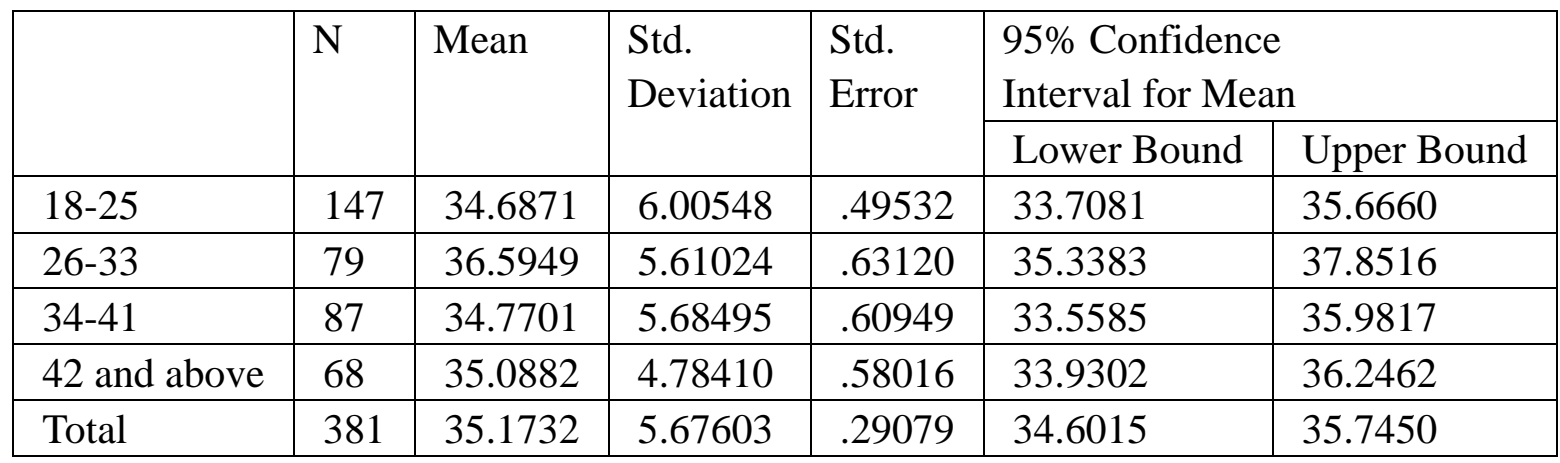

Source: Field Survey 2018

Table 3 shows satisfaction based on Age. As it reveals that it is not significant at $5 \%$ level so we use mean difference. Age 18 - 25 with a mean of 34.19 is more satisfied. It may be a reason for age coherent. Most of them at this age bracket may not be obviously oriented that need fast, urgent as higher level service requirement. What they concentrate on is chatting, Facebook, Instagram and so on, but not conferencing. Age 34 - 41 is next on satisfaction with the mean score of 34.77 followed by age 42 and above with mean score of 35.09 . The least satisfied are those in age bracket 26-33 with a mean score of 36.59. This is the active working age that requires high-level usage of the offerings. These age groups are those who have more challenges in terms of employment, business management and so on and they cannot afford to lose any call or any SMS.

\section{Equation 1: Perceive satisfaction according to Sex (S) and marital status (MS)}

The study was interested in whether marital status or Gender has effect perceived satisfaction with the equation below

$$
\mathrm{PS}=34.523+0.145 \mathrm{~ms}+0.3145 \text {. }
$$

The equation is not significant at $5 \%$ level of significance. Also, parameters of marital status and Gender is low ( 0.145 and 0.314 respectively) signifying that both of them has nothing to do with perceiving satisfaction. In other words, the satisfaction of customers with network providers has nothing to do with Age or Mental Status.

Table 4. Perceive satisfaction according to Sex (S) and marital status (MS)

\begin{tabular}{|l|l|l|l|l|}
\hline Model & R & R Square & Adjusted R Square & Std. The error of the Estimate \\
\hline 1 & $.029^{\mathrm{a}}$ & .001 & -.004 & 5.68856 \\
\hline
\end{tabular}

The research shows that $R$ is $.029, R^{2}$ is 0.001 and adjusted $R^{2}$ is -.004 shows that there is a week proportion of the variance for a dependent variable that is explained by the independent variable, but it can still be used for our investigation. Next, an effect of those whose expectations are met was regressed with "ease of obtaining call card", "tariff unit charged by 
network" network of quality, "network accessibility", "availability of bonuses“. These elements are those factors derived from customer and which the expectations are based upon. Expectation met $=\mathrm{f}$ (tariff cut, network quality, bonuses, network accessibility, ease of obtaining calls often reaching good)

\section{Equation 2}

Expectation met $=1.581+0.051 \mathrm{TC}+0.086 \mathrm{NQ}+0.007 \mathrm{NB}+0.257 \mathrm{NA}+0.152 \mathrm{EOC}$

For the analysis, $\mathrm{R}$ is 0.369 and $\mathrm{R}^{2}=0.136$ adjusted $\mathrm{R}^{2}=0.125$.

From the equation, network accessibility has the highest expectations met followed by ease of obtaining calls, but tariff cost, network quality and bonus do count much on expectation hence satisfaction because consumers have a way of playing around those factors. One way is to carry more than one network at the same time, with the hope that, at least one of those networks will work in the area at the particular time.

Table 5. Model Summary

\begin{tabular}{|l|l|l|l|l|}
\hline Model & R & R Square & Adjusted R Square & Std. Error of the Estimate \\
\hline 1 & $.369^{\mathrm{a}}$ & .136 & .125 & 1.063 \\
\hline
\end{tabular}

The research shows that $R$ is.369, $R^{2}$ is .136 and adjusted $R^{2}$ is .125 shows that there is a week proportion of the variance for the dependent variable that is explained by the independent variable, but it can still be used for our investigation

Next is to find the relationship between network quality and this element of offerings which include ease of obtaining a card, tariff cost, choice of networks, network accessibility and bonuses provided for usage.

\section{Equation 3}

$\mathrm{NQ}=\mathrm{f}(\mathrm{EOC}, \mathrm{TC}, \mathrm{NC}, \mathrm{NA}$ and $\mathrm{B})$

$\mathrm{NQ}=(3.334+0.014 \mathrm{TC}, 235 \mathrm{NC},-0.020 \mathrm{~B}-0.007 \mathrm{NA}+0.046 \mathrm{EOC})$

These variables were identified to show why customers use more than one network. And so, both network accessibility and bonus have a negative impact on network quality -0.007 and -0.020 respectively. The implication is that in Nigeria, they don't determine network quality. But tariff cost, ease of obtaining call card, choice of a network is positively related to network quality.

Table 6. Model Summary

\begin{tabular}{|l|l|l|l|l|}
\hline Model & $\mathrm{R}$ & R Square & Adjusted R Square & Std. Error of the Estimate \\
\hline 1 & $.320^{\mathrm{a}}$ & .102 & .090 & .737 \\
\hline
\end{tabular}

The research shows that $R$ is $.320, R^{2}$ is 0.102 and adjusted $R^{2}$ is .090 shows that there is a 
week proportion of the variance for a dependent variable that is explained by the independent variable, but it can still be used for our investigation. This study looks at post-purchase behaviour of customers to GSM offerings. More percentage of our respondents carries more than one network per time, $85 \%$ of the respondents agreed that they have one than a network with them while $15 \%$ are with only one network, from the analysis, we discover it is not significant at 5\% significant level. It was revealed that those that are more satisfied are those that are those use ETISALAT with the mean of 32.600 and Standard Deviation of 5.866. But it was discovered that only 15 people out of 381 use ETISALAT. The sampled subscriber's base is low and this may be the reason why the network provider was able to satisfy better.

The next network that consumers are more satisfied with is MTN with an M of 34.86 and SD of 5.758. They have the highest sampled subscribers' base which is 236. Next is GLO with M of 35.967 and SD of 5.369. The sampled subscribers' base is 92. A subscriber complaining that GLO service is below standard in the area of data network only a few places enjoy GLO data in the area under study. Lastly Airtel with a mean of 36.21 and Standard deviation of 5.865. This network had been sold severely emerging from ECONET to ZAIN to CELTEL to AIRTEL. This might have accounted for it is being the last in forms of perceived quality.

\section{Conclusion and Recommendation}

In conclusion, GSM operators in Nigeria are not conscious of the inconveniences been encountered by their subscribers, and so, they do less to take care of those subscribers. The subscribers on their own, being face with in-elastic demand for GSM service has design several methods to cope with the situation as they find themselves. This study supports others studies that subscribers are not satisfied with GSM service in Nigeria. Therefore, the only situation to improve the quality of service is to educate the subscribers on their right and privileges as a customer, and those rights and privileges to be enforced by the supervisory organ of Government consumer protection council responsible for network services which are Nigeria Communication Commission (NCC). If the entire network is performing as to expectation, there is no need to carry two networks at the same time and the competition could now be well defined, that is, those who are customers of MTN will use only one network and also those with GLO or AIRTEL will stick with only one network. The competition will now be between two or more network and it will be easy to access their competition and their competitiveness.

The Nigeria market is large enough for all the networks to operate successfully if their service is as defined by customers.

\section{Acknowledgement}

This paper and the research behind it would not have been possible without the support of Tertiary Education Trust Fund (TETFUND), an Institution - Based Research and Development Intervention in Nigeria. I am grateful for the sponsorship.

\section{References}

Ajzen, I., \& Fishbein, M. (1980). Understanding attitudes and predicting social behaviour. 
New Jersey: Preventive Hall.

Anjali, P. K. (2018). Mobile phone usage among people of various age group. International research journal management socio Home, 9(3), 2018.

Amanda, B. D., \& Alice, H. (2000). Stereotype as dynamic constructs: women and men of the past, present and future. Personality and Social Psychology Bulletin, 26, 1171-1181. https://doi.org/10.1177/0146167200262001

Barbara, E. K. (1998). Dynamic relationship with customers: High-variety strategies. Journal of the Academy of Marketing, 26, 47-53. https://doi.org/10.1177/0092070398261005

Beckett, A., Hewer, P., \& Howcroft, B. (2001). An exposition of consumer behaviour in the financial services industry. International Journal of Bank Marketing, 18(1), 15-26. https://doi.org/10.1108/02652320010315325

Bolton, R. N. (1998). A dynamic model of the duration of the customer's relationship with a continuous service provider: the role of satisfaction. Marketing Science, 17(1), 45-65. https://doi.org/10.1287/mksc.17.1.45

Booz, A., \& Hamilton (1995). Mobilfunk. Frankfurt/M.: IMK.

Cha, Seong-Soo, \& Seo, Bo-Kyong (2018). Smart Phone use and smart phones addition in middle school students in Korea: prevalence, socio networking and game use. Health Pyscology Open, 5(1). https://doi.org/10.1177/2055102918755046

Danaher, P. J., \& Rust, R. T. (1996). Indirect financial benefits from service quality. Quality Management Journal, 3(2), 63-75. https://doi.org/10.1080/10686967.1996.11918728

Dhandabani, S. (2010) Linkage between service quality and customers loyalty in commercial banks. International Journal of Management \& Strategy, 1(1), 1-22.

Gerpott, T. J., Rams, W., \& Schindler, A. (2001). Customer retention, loyalty, and satisfaction in the German mobile cellular telecommunications market. Telecommunications Policy, 25(2001), 249-269. https://doi.org/10.1016/S0308-5961(00)00097-5

Heeks, R. (2008). Meet Marty Cooper-the inventor of the mobile phone. BBC, 41(6), 26-33. https://doi.org/10.1109/MC.2008.192

Hossain, M. M., \& Suchy, N. J. (2013). Influence of Customer Satisfaction on Loyalty: A Study on Mobile Telecommunication Industry. Journal of Social Sciences, 9(2), 73-80. https://doi.org/10.3844/jssp.2013.73.80

James, F. E., Roger, D. B., \& Paul, W. M. (1994). Consumer Behaviour (8th ed.). Fort Worth, Tx Dryden.

Jeffrey, I. (2001). The role of sensory-specific satiety in attribute-level variety seeking. Journal of Consumer Research, 28, 105-120. https://doi.org/10.1086/321950

John, A, H., \& Jagdish, N. S. (1969). The theory of buyer behaviour. New York, Willery. 
Krejcie and Morgan Table (2016). Research Guide Krejcie and Morgan Table for Determining Sample Size, Sample Size, Sample Size determination, Sample Size determination for finite population, Sample Size Determination Formula. permalink, Kenya Projects Organization. Copyright KENPRO, 2009-2017.

Loke, S., Taiwo, A. A., Salim, H. M., \& Downe, A. G. (2011). Service Quality and Customer Satisfaction in a Telecommunication Service Provider. Singapore: International Conference on Financial Management and Economics, IPEDR, 11(2011), 24-29.

Mackintosh, N. J. (1983). Conditioning and Associate Learning. New York, Oxford University Press.

Mary, F. L., James, K. B., \& John, W. P. (2001). Emotional Decisions Tradeoff difficulty and coping in consumer choice. B Chicago: University of Chicago Press.

Menou, A., Homburg, C., \& Beuton, N. (2005). Understanding customer value in Business to Business Relationships. Journal of Business to Business Marketing, 12(2), 1-38. https://doi.org/10.1300/J033v12n02_01

Mendez-Apavicio, M. D., Izquierdo-Yusta. A., \& Jimenz-Zarco. A, L. (2017). Comsumer expectations of online services in the insurance industry. An exploratory study of drivers and outcomes. Journal of front psycol, 8, 1254. https://doi.org/10.3389/fpsyg.2017.01254

Muhammed. A. J., \& Jiang, Y., Abdul, W., Mohammed, S. J., \& Mohammed, F. (2019). Customers' Expectation, Satisfaction, and Repurchase Intention of Used Products Online: Empirical Evidence From China. Sage open, 9(2). https://doi.org/10.1177/2158244019846212

Morton, I. J. (1995). Broad Loyalty / Variety Seeking and the Consumer's personality: comparing children and young adults. American Psychology Association, pp. 144-151.

Murray, A. B. (2013). The real value proposition-crafting unique experiences at compelling prices. Toronto. https://doi.org/10.3138/9781442696488

Ndukwe, Ernest C. A. (2004). An Overview of the Nigerian Telecommunications.

Nimako, S. G. (2012) 'Linking Quality, Satisfaction and Behaviour Intentions in Ghana's Mobile Telecommunication Industry' European Journal of Business and Management, Vol 4 (7), 1-18.

Nimako, S. G. (2012). Linking Quality, Satisfaction and Behaviour Intentions in Ghana's Mobile Telecommunication Industry. European Journal of Business and Management, 4(7), $1-17$.

Oliver, R. L. (1996). Satisfaction: A Behavioral Perspective on the Consumer. McGraw-Hill, New York, NY.

Parker, C., \& Mathews, B. P. (2001). Customer Satisfaction: contrasting academic and consumers' expectations. Marketing Intelligence and Planning, 19(1), 38-44.

https://doi.org/10.1108/02634500110363790 


\section{Macrothink}

Business and Economic Research ISSN 2162-4860 2020, Vol. 10, No. 4

Peng, L., \& Wang, Q. (2006). Impact of relationship marketing tactics (RMTs) on switching and stayers in a competitive service industry. Journal of Marketing Management, 22, 25-59. https://doi.org/10.1362/026725706776022263

Reichheld, F. F., \& Sasser, W. E. (1990). Zero and underlying reasons. Larger sample size in the future defections: Quality comes to service. Harvard Research Business Review, 68, $105-113$

Ronald, E. G., \& Charles, F. H. (1991). Measuring consumer innovativeness. Journal of the Academy of Marketing Science, 19, 209-221. https://doi.org/10.1007/BF02726497

Rust, R. T., \& Oliver, R. L. (1994). Service Quality: Insights and Management Implications from the frontier. In R. Rust \& R. R. Oliver, (Eds.), Service Quality: New Directions in Theory and Practice (pp. 1-20). Sage Publications, Thousand Oaks, CA.

https://doi.org/10.4135/9781452229102.n1

Sajeed, V., \& Shorley, W. (2003). Consumer involvement in relationship marketing of services. Journal of Services Research, 83. https://doi.org/10.1177/1094670503254287

Siddiqi, K. O. (2011). Interrelations between Service Quality Attributes, Customer Satisfaction and Customer Loyalty in the Retail Banking Sector in Bangladesh. International Journal of Business and Management, 6(3), 12-36.

Siobhan, F. (2002). (Case study) Factors Shaping Successful Public-Private Partnerships in the ICT Sector In Bangladesh Bangladesh Enterprise Institute (BEI). Telecommunication. Journal of Marketing, 11(5), 307-317.

Salim, H. M. and Downe, A. G. (2011) Service Quality and Customer Satisfaction in a Telecommunication Service Provider. Singapore: International Conference on Financial Management and Economics, IPEDR. 11(2011), 24-29.

Thakur, S. (2011). Service quality, customer satisfaction and customer loyalty: a study with special reference to Indian banking industries. The Journal of Sri Krishna Research \& Educational Consortium, 1(5), 83-93.

Valerie, A., \& Zeithamil (1981). How Consumer evaluation process differs between goods and services. American Marketing Association. pp. 186-190.

Vavra, T. G. (1997). Improving Your Measurement of Customer Satisfaction: A Guide to Creating, Conducting, Analyzing, and Reporting Customer Satisfaction Measurement Programs. ASQ Quality Press.

Wojuade, J. I. (2005). Impact of a global system for mobile telecommunication on the Nigerian economy.

Yamanda, K. (2019). Effect of customer expectations for consumer behaviour in reputable information site. Journal direct, 79, 684-689. https://doi.org/10.1016/j.procir.2019.02.036 


\section{Copyright Disclaimer}

Copyright for this article is retained by the author(s), with first publication rights granted to the journal.

This is an open-access article distributed under the terms and conditions of the Creative Commons Attribution license (http://creativecommons.org/licenses/by/4.0/). 